Animal Health Research Institute, Assiut Branch.

\title{
STUDYING THE OCCURRENCE OF CLUMPING FACTOR GENE IN STAPH AUREUS ISOLATED FROM CASES OF SUBCLINICAL MASTITIS AND THE EFFECT OF SUCH PATHOGEN ON MILK COMPOSITION
}

(With 5 Tables and 2 Figures)

By

KH.A.S. EL-KHABAZ; M.F. HUSSIEN;

EMAN M. ABD-EL NASER and HANAA A. AHMED*

* Dept. of Biotechnology, Animal Health Research Institute

(Received at 15/3/2011)

دراسة تواجد جين عامل التجمع فى ميكروب المكور العنقودى الأهبى المعزول

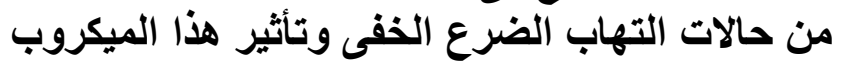
على مكونات اللبن

خالد أحمد سبي الخباز ، محمود فرغلى حسبن ، إيمان محمد عبد الناصر هناء عبل القادر أحمد فئ فئ

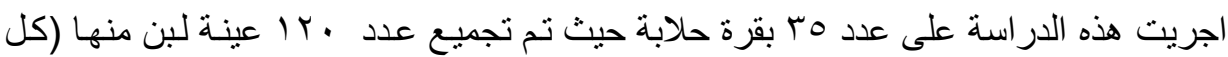

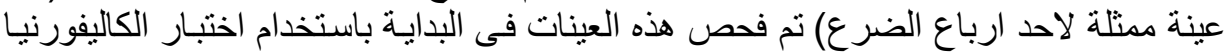

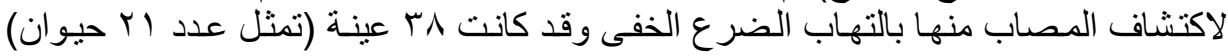

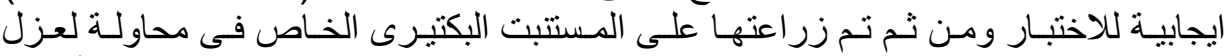

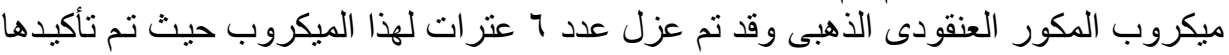

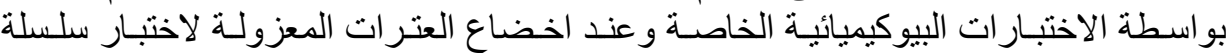

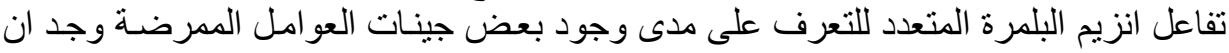

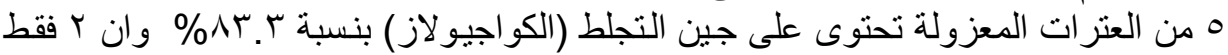

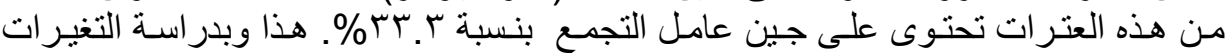

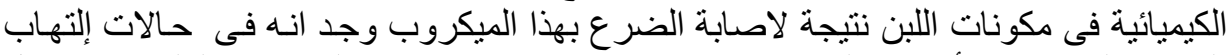

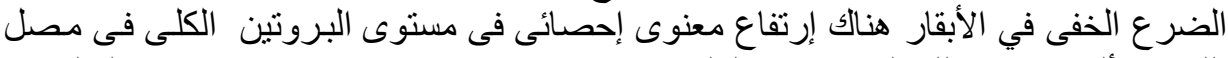

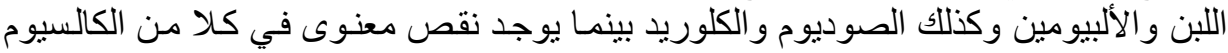

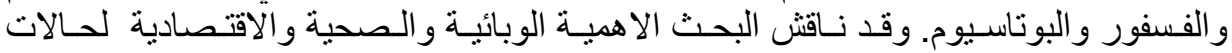
التهاب الضرع الناتج عن الاصنابة بهذا الميكروب. 


\section{SUMMARY}

120 milk samples (represent 35 cows) were randomly collected from different small holder farms, firstly tested for subclinical mastitis by CMT. 38 CMT positive samples were subjected for conventional methods of isolation and identificacion of Staph aureus. 6 isolates of Staph aureus were isolated which were subjected for genotypical characterization for the presence of clumping factor and coagulase genes by PCR assay using oligonucleotide primers that amplified genes encoding cluming factor ( clfa)gene, and (coa)gene. The results of PCR assay revealed that 5 isolates of Staph aureus were positive for coagulase gene, while 2 isolates were positive for clumping factor gene. The chemical analysis of milk showed that there were significant statistical increase in total whey protein, albumin, sodium and chloride in cows' milk samples with subclinical mastitis. While, there was a significant decrease in both calcium, phosphorous and potassium levels in comparing with the normal milk. The present study was carried out to study the presence of some virulence factors genes in Staph aureus isolated from bovine subclinical mastitis which is very important prerequisites for implementation of effective control programs to face the economic losses due to subclinical mastitis caused by this microorganism.

Key words: Milk, subclinical mastitis, clumping factor gene, Staph aureus.

\section{INTRODUCTION}

Subclinical mastitis, without any signs of inflammation compared with clinical mastitis is accounts for the majority of bovine mastitis cases in dairy herds (Oliver et al., 2004). Staphylococcus aureus is recognized worldwide as a frequent cause of subclinical intramammary infections in dairy cows. The main reservoir of $S$. aureus seems to be the infected quarter, and transmission between cows usually occurs during milking. S. aureus produces a spectrum of extra cellular protein toxins and virulence factors which are thought to contribute to the pathogenicity of the organism (Momtaz et al., 2010)

$S$. aureus seems to be the predominant organism causing subclinical mastitis (Kader et al., 2002) and it may predispose the herd for infection by coliforms or other pathogens (Ibtisam et al., 1993).

$S$. aureus is usually considered the most common contagious pathogen and has been reported to infect 7 to $40 \%$ of all cows (Fox and Gay, 1993). 
Staph aureus has a capacity to produce a large number of putative virulence factors (Fitzgerald et. al., 2000). Some of these factors may be of more importance than others in different diseases or at different stages of the pathogenesis of particular infections, as not all factors are produced by each strain (Kalorey et al., 2007). Natural populations of $S$. aureus have shown considerable variability in genome content (Phonimdaeng et al., 1990 and Fitzgerald et al., 2003), this variability has contributed to the emergence of distinct epidemiologic profiles that are dependent on the strains prevalent in a herd, which suggests the need to identify such strains or subtypes before applying specific measures to control mastitis (Zecconi and Piccinini 1999).

Molecular epidemiological analysis of the bovine $S$. aureus population suggested that small number of clonal types were responsible for most infections and those strains had abroad geographic distribution (Fitzgerald et al., 1997 and Salasia et al., 2004)

The ability of $S$. aureus to adhere to extracellular matrix proteins is thought to be essential for the colonization and the establishment of infections (El-Sayed et al., 2005). S. aureus possesses various adhesion genes, including $c l f A, f n b A$, and cna (Smeltzer et al., 1997). Genetic characterization of mastitis-causing $S$. aureus isolates is vital for an effective mastitis control program, especially for developing a vaccine against $S$. aureus (LI et al., 2009).

Kalorey et al. (2007) stated that clfA gene play an important role in the pathogenesis of bovine mastitis. The role of $C l f A$ as a virulence factor was shown in an endocarditis model, where the $c l f A$-defective mutant produced about 50\% less endocarditis than the parent strain (Moreillon et al., 1995).

The coa gene is one of the most important virulence factors for S. aureus (Goh et al., 1992). Expression of this gene is thought to enhance bacterial growth and promote infection in the face of host defence mechanisms, such as phagocytosis (Aarestrup et al., 1995).

Mastitis, particularly the subclinical type, influences the total milk output and modifies milk composition and technological usability. Subclinical mastitis is associated with altered protein quality, change in fatty acid composition, lactose, ion and mineral concentration, increased enzymatic activity, and a higher $\mathrm{pH}$ of raw milk (Auldist et al., 1996 and Coulon et al., 2002). Mastitis is accompanied by significant modifications of milk chemical composition (Anwer et al., 2003) with both a reduced synthesis and altered cell permeability. Such 
modifications affect protein and mineral fractions, in particular, carry major consequences for milk appear Linked with the technological properties (Batavani et al., 2007) and appear linked with the mastitis germ.

The present study was conducted to phenotypically and genptypically characterize $S$. aureus isolates in milk samples from cows with subclinical mastis in addition to studying the changes in milk composition associated with such pathogen.

\section{MATERIALS and METHOSD}

\section{Milk samples}

120 quarter milk samples were collected from 35 dairy cows selected randomly from small different farms. Animals were physically and clinically investigated to exclude clinical mastitis. The milk samples were tested by California mastitis test (CMT) for subclinical mastitis according to Schalm et al. (1971). CMT scored from one to five corresponding to no reaction, trace, mild reaction, moderate reaction, strong reaction, respectively. The positive samples were subjected to bacteriological examination.

\section{Bacteriological examination:- A- Isolation of S.aureus}

The milk samples were incubated at $37{ }^{\circ} \mathrm{C}$ for $18-24 \mathrm{~h}$ and $10 \mathrm{ml}$ of the milk samples were transferred into sterile small centrifuge tubes. The tubes were centrifuged at 3000rpm for $20 \mathrm{~min}$ and then the cream and supernatant were discarded to obtain the sediment, loopful from the milk sediment was inoculated into 10\% Nacl broth (A.P.H.A., 1985), then incubated at $37^{\circ} \mathrm{C}$ for $24 \mathrm{~h}$. From the incubated tubes loopfuls were streaked onto the surface of mannitol salt agar plates (Bailey and Scott, 1994), the inoculated plates were incubated aerobically at 37 for $24 \mathrm{~h}$.

The mannitol fermenting pure cultures (surrounded by a yellow hallo) were streaked on blood agar plates and incubated for detection of haemolysis

\section{B-Identification of S. aureus:}

Colonies of $S$. aureus on blood agar which is golden, brown, yellow or pink, domed 1-3 mm in diameter (Collins et al., 1991), and identified by Gram's stain as cocci arranged in clusters or bunches, colonies confirmed biochemically according to (Quinn et al., 1994) using catalase and coagulase tests (slide method). 


\section{C- Identification of S.aureus genotypically by PCR assay for the presence of coagulase and clumping factor genes:}

DNA extraction: $2 \mathrm{ml}$ of previously enriched $S$. aureus isolates were centrifuged at $14000 \mathrm{RPM}$, then the sediment is suspended in $50 \mu \mathrm{l}$ of distilled water. The cellular suspension was brought to boil during $10 \mathrm{~min}$, and immediately was centrifuged at 14,000 RPM for 5 min. The supernatant was directly used for the PCR assay (Franco et al., 2008).

Oligonucleotide primers used encoding coagulase positive (coa) gene were $C o a$-1 CGA GAC CAA GAT TCA ACA AG and Coa -2 AAA GAA AAC CAC TCA CAT CA with initial denaturation at $94^{\circ} \mathrm{C}$ for $10 \mathrm{~min}$ followed by 35 cycle of $94^{\circ} \mathrm{C}$ for $1 \mathrm{~min}, 58^{\circ} \mathrm{C}$ for $1 \mathrm{~min}$ and $72^{\circ} \mathrm{C}$ for $1 \mathrm{~min}$, with final extension of $10 \mathrm{~min}$ at $72^{\circ} \mathrm{C}$ (Aslantas et al., 2007) and clumping factor A (clfA) gene forward: GGC TTC AGT GCT TGT AGG, reverse: TTT TCA GGG TCA ATA TAA GC with initial denaturation at $94^{\circ} \mathrm{C}$ for $10 \mathrm{~min}$ followed by 35 cycle of $94^{\circ} \mathrm{C}$ for $1 \mathrm{~min}$, $57^{\circ} \mathrm{C}$ for $1 \mathrm{~min}$ and $72^{\circ} \mathrm{C}$ for $1 \mathrm{~min}$, with final extension of $10 \mathrm{~min}$ at $72^{\circ} \mathrm{C}$ (Kalorey et al., 2007). The PCR products were electrophoresed on 1.5\% agarose gel using GeneRuler 100 bp plus DNA Ladder (Fermentas)

Table 1: Primers used for amplification of some $S$. aureus genes

\begin{tabular}{|l|l|}
\hline Gene & Sequences \\
\hline Coa & $\begin{array}{l}\text { CGA GAC CAA GAT TCA ACA AG } \\
\text { AAA GAA AAC CAC TCA CAT CA }\end{array}$ \\
\hline clfA & $\begin{array}{l}\text { GGC TTC AGT GCT TGT AGG } \\
\text { TTT TCA GGG TCA ATA TAA GC }\end{array}$ \\
\hline
\end{tabular}

\section{Chemical analysis:}

Sample preparation:

Fresh raw milk was obtained from cows. Within an hour after milking, milk was skimmed by centrifugation at 3000 r.p.m for $15 \mathrm{~min}$ to remove their creams and cells. Samples were then treated with 0.1 M., hydrochloric acid at the controlled $\mathrm{pH}$ of 4.8 for casein precipitation. Treated samples were recentrifuged and the supernatants (Whey) were collected. Total protein, albumin, calcium, phosphorous, and chloride, levels were measured by using spectrophotometer through reagent kits supplied commercially by (STANBIO laboratories). Sodium and potassium measured by flame photometer.

Statistical Analysis:

Student's t-test was carried out to fined the differences between the results of mastitic and non mastitic milk samples. The results were given as mean $\pm \mathrm{SEM}$. 


\section{RESULTS}

Table 2: Quarter -wise prevalence of subclinical mastitis in cows milk samples based on the results of CMT and Bacteriological examination

\begin{tabular}{|c|c|c|c|c|c|c|c|c|}
\hline $\begin{array}{c}\text { No of } \\
\text { quarters }\end{array}$ & \multicolumn{2}{|c|}{$\begin{array}{c}\text { CMT } \\
\text { positive }\end{array}$} & \multicolumn{2}{|c|}{$\begin{array}{c}\text { Positive samples } \\
\text { for S. aureus }\end{array}$} & \multicolumn{2}{|c|}{$\begin{array}{c}\text { CMT } \\
\text { negative }\end{array}$} & \multicolumn{2}{|c|}{$\begin{array}{c}\text { Negative smples } \\
\text { for } S . \text { aureus }\end{array}$} \\
\hline \multirow{2}{*}{120} & No & $\%$ & No & $\%$ & No & $\%$ & No & $\%$ \\
\cline { 2 - 9 } & 38 & 31.7 & 6 & 5 & 82 & 68.3 & 114 & 95 \\
\hline
\end{tabular}

Table 3: Prevalence of subclinical mastitis in cows based on CMT

\begin{tabular}{|c|c|c|c|c|}
\hline $\begin{array}{c}\text { No. } \\
\text { of cows }\end{array}$ & \multicolumn{2}{|c|}{ CMT positive } & \multicolumn{2}{c|}{ CMT negative } \\
\hline \multirow{2}{*}{35} & No. & $\%$ & No. & $\%$ \\
\cline { 2 - 5 } & 21 & 60 & 14 & 40 \\
\hline
\end{tabular}

Table 4: Incidence of coagulase (coa) and clumping factor ( $c l f A)$ genes in staph aureus isolates

\begin{tabular}{|c|c|c|c|c|}
\hline S.aureus isolates & \multicolumn{2}{|c|}{+ ve isolates for coa gene } & \multicolumn{2}{c|}{+ ve isolates for $c l f A$ gene } \\
\hline No & No & $\%$ & No & $\%$ \\
\hline 6 & 5 & 83.3 & 2 & 33.3 \\
\hline
\end{tabular}

Table 5: Changes in some chemical constituents of milk as a result of subclinical mastitis

\begin{tabular}{|c|c|c|c|}
\hline Parameters & units & Normal milk & SCM milk \\
\hline Total protein & $\mathrm{g} / \mathrm{L}$ & $31.4 \pm 1.3$ & $34.3 \pm 1.5^{*}$ \\
\hline Albumin & $\mathrm{g} / \mathrm{dI}$ & $2.87 \pm 0.09$ & $5.81 \pm 0.14^{*}$ \\
\hline Calcium & $\mathrm{mg} / \mathrm{dl}$ & $107.4 \pm 1.26$ & $90.8 \pm 1.91^{*}$ \\
\hline Phosphorous & $\mathrm{mg} / \mathrm{dl}$ & $25.51 \pm 0.32$ & $19.30 \pm 0.22^{*}$ \\
\hline Chloride & $\mathrm{mmol} / \mathrm{L}$ & $28 \pm 21$ & $35 \pm 27^{*}$ \\
\hline Sodium & $\mathrm{mg} / \mathrm{dl}$ & $49.72 \pm 1.20$ & $87.97 \pm 4.32^{*}$ \\
\hline Potassium & $\mathrm{mg} / \mathrm{dl}$ & $155.74 \pm 1.9$ & $139.56 \pm 2.1^{*}$ \\
\hline
\end{tabular}

*Significant at $\mathrm{p}<0.01$ 


\section{DISCUSSION}

S. aureus has been recognized as a pathogen in human and animal. Sublinical mastitis causes considerable loss to the dairy industry of which $S$. aureus is probably the most lethal agent because it causes chronic and deep infection in the mammary glands that is extremely difficult to be cured.

Out of 120 quarter cows milk samples examined 38(31.7\%) were positive for subclinical mastitis based on the results of CMT (Table 2). These results were lower than that recorded by Sharma and Rai (1977), Ismail and Hatem (1998) and Nazem and Azab (1998) as they recorded $40.43,67.7$ and $75.25 \%$, respectively, while the results of this study are in accordance for some extent to that mentioned by Sadek (2008) $28.5 \%$. The subclinical mastitis incidence varied widely due to changing management condition (Radostitis et al., 2000).

Depending on the results of CMT, animal prevalence of subclinical mastitis has been illustrated in (Table 3), out of 35 dairy cows examined, 21 animals $(60 \%)$ gave positive results, nearly similar results were recorded by Sexena et al. (1993) 64\%, while lower results were recorded by Li et al. (2009) 54.3\%, Tijare et al. (1999) 16.6\% and Sadek (2008) 59.05\%.

S. aureus is one of the contagious organisms that well adopted to survive in the udder and usually establish mild subclinical infection for long duration (El- khodery and Hoedemakes, 2005) and can spread from infected quarter to another quarter (El-Balkemy et al., 1997). Staphyococci typically colonize the broken skin and can enter the udder through abrasions of the teat (Dhakal, 1997).

Generally $S$. aureus is commonly isolated from subclinical mastitis cases (Abdel-Khalek and El-Sherbini, 2005) due to its ability to develop sophisticated system to avoid phagocytosis or macrophages (Vanfuth and Zwet, 1986).

The prevalence of subclinical mastitis caused by $S$. aureus were studied by many investigators, the obtained results $(5 \%)$ come in coincides with the results of Fox and Gay (1993) as they stated that S. aureus mastitis in cattle ranged from 7- $40 \%$, while it was lower for high extent than that recorded by Janosi and Balty(2004). Attia et al. (2003) and Shitandi and Kihumbu, (2004) which were, 80\%, 60\% and $45.6 \%$, respectively.

Prevalence and etiology of subclinical mastitis in dairy animal show that coagulase-negative staphylococci are the most prevalent, ranging from $25 \%$ to $93 \%$ (mean value approximately $78 \%$ ) of bacterial 
isolates. S. aureus prevalence ranges from $3 \%$ to $37 \%$ (mean value approximately 4\%) of the bacterial isolates (Janosi and Balty (2004).

Several genotypic techniques have been developed in the last decades. The coagulase protein is an important virulence factor for $S$. aureus. The coagulase gene amplification has been considered a simple and accurate method for typing. This method is found to be technically simple with a good reproducibility and discriminatory power (Karahan and Cetinkaya, 2007). The coa gene has polymorphic repeat regions that can be used for differentiating $S$. aureus isolates (van Belkum et al., 1998).

Table (4) and photo (1) showing that six identified field isolates by biochemical tests were tested for the presence of coa gene. 5 samples were positive to this gene $(83.3 \%)$ with different polymorphism. Two isolates gave one band at $200 \mathrm{bp}$, one gave two bands at 970 and $200 \mathrm{bp}$ and one gave at one band at $970 \mathrm{bp}$ and one isolate gave one band at 910 bp.

The variability in size and number of Coa bands seen in this study may be due to presence of structurally different gene forms of coagulase in $S$. aureus, allowing one strain to produce one or more of these variants (Goh et al., 1992).

Studies carried out on PCR amplification of coa gene in different countries using the same primer pairs revealed extensive polymorphism with predominance of one or more of coa gene amplified products among $S$. aureus responsible for mastitis in cows and buffaloes. Annemuller et al. (1999) obtained four PCR products of 990, 900, 800, and $740 \mathrm{bp}$, with 990 bp being the predominant product. Lange et al. (1999) found seven PCR products ranging from 580 to 1060 bp Guler et al. (2005) obtained 1000-, 900-, 800-, and 700-bp PCR products while Katsuda et al. (2005) found five types of amplified products ranging from $420+$ $20 \mathrm{bp}$ to $820+20$ bp. Vimercati et al. (2006) observed amplified products of coa gene ranging from 420 to $900 \mathrm{bp}$. Saei et al. (2009) observed five different PCR products with molecular weight ranging from 490-850 bp in a study in nine dairy herds. PCR amplification of the 30 end of the coa gene showed that $161(80.5 \%)$ of $S$. aureus isolates were coa positive (Akineden et al., 2001).

The proportion of coa positive isolates varied from $0 \%$ to $100 \%$ by geographic location (Karahan and Cetinkaya, 2007). The predominance of one or more coa gene genotypes may be more beneficial in the control of Staphylococcus aureus mastitis since they were reported to be more resistant to neutrophil bactericidal activities 
than rare genotypes ( $\mathrm{Su}$ et al., 1999). It also suggests a common source, host to host transmission i.e. contagious transmission, host adaptation of subsets of the population of $S$. aureus strains. Also, differences in distribution of coagulase gene variants $S$. aureus may reflect presence of virulence factors responsible for suppressing host defence mechanisms (Goh et al., 1992).

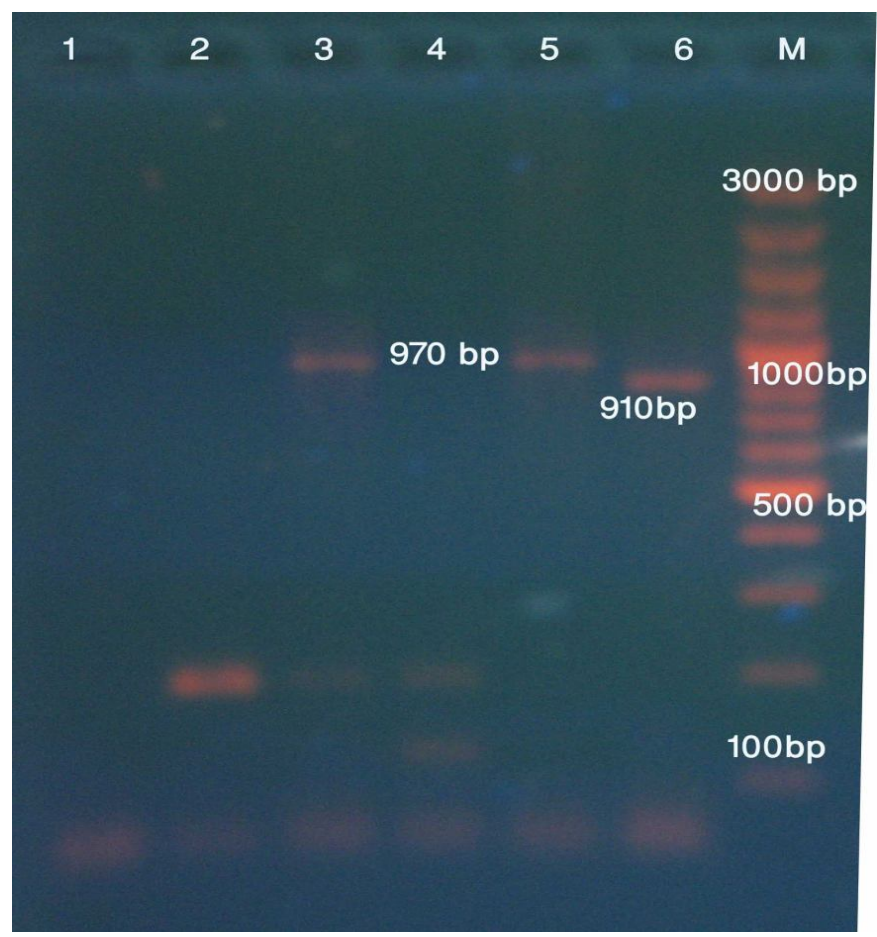

Photo (1): Electrophoretic pattern of coagulase (coa) gene in different isolates

1-Negative control

2- Staphylococcus aureus field isolate (1)

3- Staphylococcus aureus field isolate (2)

4-Staphylococcus aureus field isolate (3)

5-Staphylococcus aureus field isolate (4)

6-Staphylococcus aureus field isolate (5)

7-Marker GeneRuler (Fermentas)

Clumping factor A $(C l f A)$ is considered one of most important adhesion factors and has been identified as a virulence factor in an endocarditis model in human (McDevitt et al., 1995). It is a cell wallanchored $S$. aureus surface protein that has been shown to enhance 
staphylococcal virulence in animal infection models. From Table (4) and photo (2) It is clear that clumping factor gene ( $c l f A$ ) was detected only in two isolates out of the tested six isolates with a characteristic band at $1042 \mathrm{bp}$ in a percentage of $33.3 \%$ indicating no size polymorphism to this gene. These results agreed with Akineden et al. (2001) and Momtaz et al. (2010). These positive samples were also positive to the presence of coa gene. Presence of the clf $A$ gene Staphylococcus spp virulence gene has its importance in development of severity of mastitis (Akineden et al., 2001). The phenotypic and genotypic results of the present study might help to understand the distribution of prevalent $S$. aureus clones among bovine mastitis isolates of both countries and might help to control $S$. aureus infections in dairy herds.

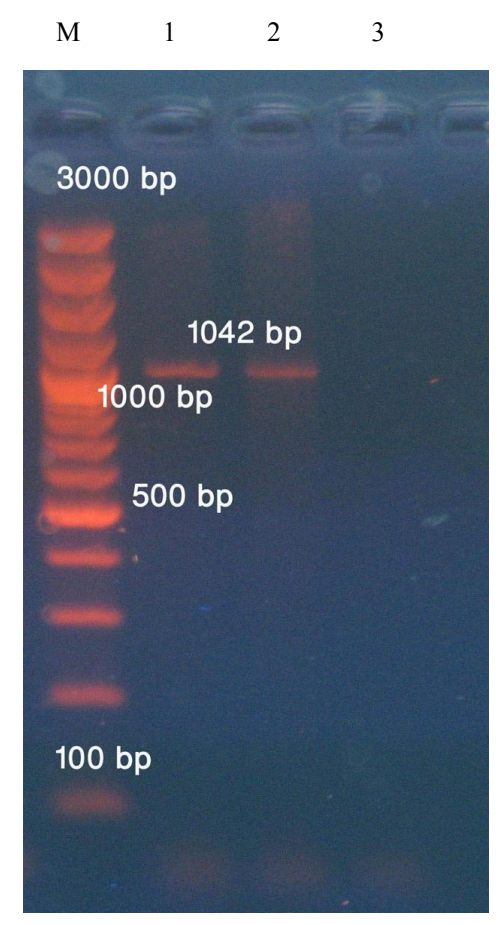

Photo 2: Electrophoretic pattern of clumping factor A (clfA) gene in different isolates

M-Marker GeneRuler (Fermentas)

1- Staphylococcus aureus positive field isolate (4)

2- Staphylococcus aureus positive field isolate (5)

3- Negative control 
It is generally accepted that during subclinical mastitis, there is an increase in milk proteins (Leitner et al., 2004) that has been attributed to the influx of blood borne proteins (such as serum albumin). According to Auldist and Hubble (1998) this increase in proteins of blood serum origin during mastitis is possibly due to disruption to the integrity of the mammary epithelia by microbial toxins and opening of the tight junctions.

The increase of albumin content during mastitis has been reported in cows Vijayalakshmi et al., 2001; Coulon et al., 2002 and Batavani et al., 2007).

The significant increase of albumin in Subclinical mastitic milk suggest that a major source of the increase in the content of albumin in milk under inflammatory conditions is the mammary gland itself (Shamay et al., 2005).

The levels of calcium and phosphorous is also affected by SCM. There were a significant $(\mathrm{p}<0.01)$ decrease in both calcium and phosphorous levels. The reduction in both calcium and phosphorus level in the case of intramammary infections have been reported by (Coulon et al., 2002 and Batavani et al., 2007).

Sub clinical mastitis changed the ionic environment. Sodium and chloride showed significant increase in contract, potassium; normally the predominant mineral in milk is declined. These increases in sodium and chloride and decrease in potassium levels have been confirmed by other authors as methods of monitoring udder health (Vijayalakshmi et al., 2001 and Bruckmaier and Blum 2004).

\section{REFERENCES}

A.P.H.A (1985): Standard Methods for the Examination of Dairy Products 15th., American Public Health Association Washington, D.

Aarestrup, F.M.; Dangler, C.A. and Sordillo, L.M. (1995): Prevalence of coagulase gene polymorphism in Staphylococcus aureus isolates causing bovine mastitis. Canadian Journal of Veterinary Research.59: 124-128.

Abdel-Khalek, A. and El-Sherbini, M. (2005): Prevalence of contagious pothogens of bovine subclinical mastitis and relationship to bacterial and somatic cell counts. 4th Int.Conf.,Mansoura 1-10. Akineden, Ö.; Annemüller, C.; Hassan, A.A.; Lämmler, C.; Wolter, W. and Zschöck, M. (2001): Toxin Genes and Other 
Characteristics of Staphylococcus aureus isolates from Milk of Cows with Mastitis. Clin. Diagn. Lab Immunol. 8: 959-964. Annemüller, C.; Lämmler, C. and Zschöck, M. (1999): Genotyping of Staphylococcus aureus isolated from bovine mastitis. Vet. Microbiol., 69: 217-224.

Anwer, W.; Mohga, F. Badawi and Gehan Z. Moustafa (2003):

Environmental micro-organisms causing mastitis in dairy cattle reared under different hygienic measures. J. Egypt. Vet. Med. Associ 63, no. 1: 161-170.

Aslantas, O.; Demir, C.; Turutoglu, H.; Cantekin, Z.; Ergun, Y. and Dogruer, G. (2007): Coagulase gene polymorphism of Staphylococcus aureus isolated form subclinical mastitis. Turk.

J. Vet. Anim. Sci. 31: 253- 257.

Attia, E.R.H.; El Rashidy, A. and Metias, K.N. (2003): Comparative study between electric conductivity,California mastitis test and somatic cell count for rapid diagnosis of subclinical mastitis in lactating cows. The $7^{\text {th }}$ Sci. Cong Egyptian society cattle Diseases, pp. 25-29.

Auldist, M.J.; Coats, S.; Sutherland, B.J; Mayes, J.J.; McDowell, G.H. and Rogers, G.L. (1996): Effects of somatic cell count and stage of lactation on raw milk composition and the yield and quality of Cheddar cheese. J Dairy Res, 63: 269-280.

Auldist, M.J. and Hubble, I.B. (1998): Effects of mastitis on raw milk and dairy products. The Australian Journal of Dairy technology, 38-36.

Baily, W.R. and Scott, E.G. (1994): "Diagnostic Microbiology". A textbook for the isolation and identification of pathogenic microorganisms. 9th Ed. the C.V. Mosby, St. Louis.

Batavani, R.A.; Asri, S. and Naebzadeh, H. (2007): The effect of subclinical mastitis on milk composition in dairy cows. Iranian J. Vet. Res. 20: 205-211.

Bruckmair, R.M. and Blum, J.W. (2004): Fractionized milk composition in dairy cows with subclinical mastitis. Veterinary medicineCzech. 8 (283-290).

Collins, C.H.; Lyne, P.M. and Gran, J.M. (1991): "Microbiological Methods". 6th Ed. pp.: 127-140, Butterworth-Heinemann, Oxford.

Coulon, J.B.; Gasqui, P.; Barnouin, J. and Pomies, D. (2002): Effect of mastitis and related-germ on milk yield and composition during 
naturally-occurring udder infections in dairy cows. Anim. Res. 51: 383-393.

Dhakal, I.P. (1997): Drug selection and use on clinical mastitis in buffaloes at Chitwan Vally of Nepal. Bubalus bubalis, 11: 56-70.

El-Balkemy, F.A.; Esmat, M.; Afaf Menazie and Azza N. Farag (1997):

Evaluation of screening testes used for detection of subclinical mastitis. 4th Sci.Cong. Egyptian Society for cattle Disease, 7-9 Dec.Assiut,Egypt: 181-191.

El-Khodery, S.A. and Hoedemakes, M. (2005): Incidence and type of mastitis in the livestock of Nothern Germany concerning management factors. 4th Int.Sci.Conf., Mansoura, 5-6 April, 973-987.

El-Sayed, A.; Alber, J.; Lämmler, C.; Bonner, B.; Huhn, A.; Kaleta, E.F. and Zsch sck, M. (2005): PCR-based detection of genes encoding virulence determinants in Staphylococcus aureus from birds. J. Vet. Med. B. Infect. Dis. Vet. Public Health, 52: 38-44.

Fitzgerald, J.R.; Meaney, W.J.; Hartigan, P.J.; Smyth, C.J. and Kapur, $V$. (1997): Fine structure molecular epidemiological analysis of Staphylococcus aureus recovered from cows. Epidemiol Infect 1997, 119: 261-269.

Fitzgerald, J.R.; Hartigan, P.J.; Meaney, W.J. and Smyth, C.J. (2000): Molecular population and virulence factor analysis of Staphylococcus aureus from bovine intramammary infection. J. Appl. Microbiol., 88: 1028-1037.

Fitzgerald, J.R.; Reid, S.D. and Ruotsalainen, E. et al. (2003): Genome diversification in Staphylococcus aureus: molecular evolution of a highly variable chromosomal region encoding the staphylococcal exotoxin-like family of proteins.

Fox, L.K. and Gay, J.M. (1993): Contagious mastitis. Vet. Clin. N. Am. 9(3): 475-488.

Franco, J.; González, V.; Gómez, M.; Carrillo, G. and Ramírez, C. (2008): Virulence factors analysis of Staphylococcus aureus isolated from bovine mastitis in México, eGnosis [online j.] $67)$.

Goh, S.H.; Byrne, S.K.; Zhang, J.L. and Chow, A.W. (1992): Molecular typing of Staphylococcus aureus on the basis of coagulase gene polymorphisms. J. Clin. Microbiol., 30: 1642- 1645. 
Guler, L.; Ok, U.; Gunduz, K.; Gulcu, Y. and Hadimli, H.S. (2005): Antimicrobial susceptibility and coagulase gene typing of Staphylococcus aureus isolated from bovine clinical mastitis cases in Turkey. J. Dairy Sci., 88: 3149-3154.

Ibtisam, E.; Mohamed, G.E; Mohamed, G.E. and El-Own, O.A.O. (1993): A study on the incidence and etiology of bovine mastitis in sudan 2nd Sci. Cong.Egyptian Society for Cattle Diseases, 5-7 Dec. Assiut, Egypt, 326-332. Infect Immun, 71: 2827-2838.

Ismail, T.M. and Hatem, M.E. (1998): Prevalence of subclinical mastitis in a dairy herd in the eastern region of Saudi Arabia. Proc. $8^{\text {th }}$ Sci. Cong., Fac. Vet. Med., Assiut Univ., Egypt.

Janosi, S. and Baltay, (2004): Correlation among the somatic cell count of individual bulk milk, result of California Mastitis test and bacteriological status of the udder in dairy cows. Acta Vet Hung. 52: 173-183.

Kader, M.A.; Samad, M.A.; Seha, S. and Taleb, M. (2002): prevalence and etiology of subclinical mastitis with antibiotic sensitivity to isolated organisms among Milch cows in Bangladesh. I.J.D.S., 55, 4: 218-223.

Kalorey, D.R.; Shanmugam, Y.; Kurkure, N.V.; Chousalkar, K.K. and Barbuddhe, S.B. (2007): PCR-based detection of genes encoding virulence determinants in Staphylococcus aureus from bovine subclinical mastitis cases. J. Vet. Sci., 8(2): 151-4.

Karahan, M. and Cetinkaya, B. (2007): Coagulase gene polymorphisms detected by PCR in Staphylococcus aureus isolated from subclinical bovine mastitis in Turkey Vet. J., 174: 428-431.

Katsuda, K.; Hata, E.; Kobayashi, H.; Kohmota, M.; Kawashima, K.; Tsunemitsu, H. and Eguchi, M. (2005): Molecular typing of Staphylococcus aureus isolated from bovine mastitic milk on the basis of toxin genes and coagulase gene polymorphisms. Vet. Microbiol., 1054: 301-305.

Lange, C.; Cardoso, M.; Senczek, D. and Schwarz, S. (1999): Molecular subtyping of Staphylococcus aureus isolates from cases of bovine mastitis in Brazil. Vet. Microbiol. 67: 127-141.

Leitner, G.; Chaffer, M.; Shamay, A. and Shapiro, F. (2004): Changes in milk composition as affected by subclinical mastitis in sheep. J. of Dairy Scince, 87: 46-52.

Li, J.; Zhou, H.; Yuan, L.; He, T. and Hu, S. (2009): Prevalence, genetic diversity, and antimicrobial susceptibility profiles of 
Staphylococcus aureus isolated from bovine mastitis in Zhejiang Province, China. Journal of Zhejiang University 10(10): 753-760.

McDevitt, D.; Francois, P.; Vaudaux, P. and Foster, T. (1995): Identification of the ligand-binding domain of the surfacelocated fibrinogen receptor (clumping factor) of Staphylococcus aureus. Mol. Microbiol., 16(5): 895-907.

Momtaz, H.; Rahimi, E. and Tajbakhsh, E. (2010): Detection of some virulence factors in Staphylococcus aureus isolated from clinical and subclinical bovine mastitis in Iran. African J. of Biotechnology, 9 (25): 3753-3758.

Moreillon, P.; Entenza, J.M.; Francioli, P.; McDevitt, D.; Foster, T.J.; Francois, P. and Vaudaux, P. (1995): Role of Staphylococcus aureus coagulase and clumping factor in pathogenesis of experimental endocarditis. Infect. Immun. 63: 4738-4743.

Nazem, A.M. and Azab, M.H. (1998): Detection of apparently normal milk by screening and confirmatory methods. Pro 8th Sci Cong., Assiut Univ., Egypt.

Oliver, S.P.; Gillespie, B.E.; Headrick, S.J.; Moorehead, A.; Lunn, P.; Dowlen, H.H.; Johnson, D.L.; Lamar, K.C.; Chester, S.T. and Moseley, W.M. (2004): Efficacy of extended ceftiofur intramammary therapy for treatment of subclinical mastitis in lactating dairy cows. J. Dairy Sci., 87(8): 2393-2400.

Phonimdaeng, P.; O'Reilly, M.; Nowlan, P.; Bramley, A.J. and Foster, T.J. (1990): The coagulase of Staphylococcus aureus 8325-4. Sequence analysis and virulence of site-specific coagulasedeficient mutants. Mol. Microbiol. 4: 393-404.

Quinn, P.J.; Garter, M.E.; Markey, B.A. and Carter, G.R. (1994): Clinical Veterinary Microbiology. Published by Wolfe Publishing, an imprint of Mosby Year Book Europe Limited. Lachica RVF,Genigeorgis C,Hoeprich PD. metachromatic agar-diffusion methods for detecting Staphylococcal nuclease activity. Appl. Microbiol 1971, 21: 585-587.

Radostitis, O.M.; Gay, C.C.; Blood, D.C. and Hincheliff, K.W. (2000): Veterinary Medicine, a textbook of the diseases of cattle, sheep, pigs, goat and horses.9th Ed., W.B.Saunders co Ltd., London. 
Sadek, O.A. (2008): Huma health risks associated with consumption of milk from subclinical mastitis animals in Assiut governorate. Ph.D thesis, Fac. Vet. Med., Assiut Univ., Egypt.

Saei, H.D.; Ahmadi, M.; Mardani, K. and Batavani, R.A. (2009): Molecular typing of Staphylococcus aureus isolated from bovine mastitis based on polymorphism of the coagulase gene in the north west of Iran. Vet. Microbiol., 137(1-2): 202-206.

Salasia, S.I.O.; Khusnan, Z.; Lammler, C. and Zschock, M. (2004): Comparative studies on pheno-and genotypic properties of Staphylococcus aureus isolated from bovine subclinical mastitis in central java in Indonesia and Hesse in Germany. J. Vet. Sci., 5: 103-109.

Schalm, O.W.; Carroll, E.J. and Jain, N.C. (1971): Bovine mastitis. Philadelphia: Lea and Febiger.

Sexena, R.K.; Dutta, G.N.; Borah, P. and Buragohain, J. (1993): Incidence and etiology of bovine subclinical mastitis. Indian Vet. J., 70(11): 1079-1080.

Shamay, A.; Homans, R.; Fuerman, Y.; Levin, I. and Mabjeesh, S.J. (2005): Expression of albumin in non-hepatic tissues and its synthesis by the bovine mammary gland. J Dairy Sci., 88: 569-576.

Sharma, S.D. and Rai, P. (1977): Studies on the incidence of bovine mastitis in Uttar Pradesh 11. Subclinical mastitis. Indian VET.J., 54(6): 435-439.

Shitandi, A. and Kihumbu, G. (2004): Assessement of the California mastitis test usage in small holder dairy herds and risk of violative antimiaobila residues. J. Dairy Sci. 92: 4962-4970.

Smeltzer, M.S.; Gillaspy, A.F.; Pratt, F.L. J.R.; Thames, M.D. and Iandolo, J.J. (1997): Prevalence and chromosomal map location of Staphylococcus aureus adhesin genes. Gene, 196: 249-259.

Su, C.; Kanevsky, I.; Jayarao, B.M. and Sordillo, L.M. (2000): Phylogenetic relationships of Staphylococcus aureus from bovine mastitis based oncoagulase gene polymorphism. Veterinary Microbiology 71: 53-58.

Su, C.; Herbelin, C.; Frieze, N.; Skardova, O. and Sordillo, L.M. (1999): Coagulase gene polymorphism of Staphylococcus aureus isolates from dairy cattle in different geographical areas. Epidemiol. Infect., 122: 329-336. 
Tijare, D.B.; Singh, A.K.; Chaturvedi, V.K. and Dhanesas, N.S. (1999): Sensitivity of indirect testes in detection of subclinical mastitis in buffaloes.Indian Vet.J., 76(10) 912-915.

Van Belkum, A.; Scherer, S.; Van Alphen, L. and Verbrugh, H. (1998): Short sequence DNA repeats in prokaryotic genomes. Microbiol Mol. Biol. Rev., 62: 275-93.

Vanfurth, R. and Van Zwet, T. (1986): In vitro determination of phagocytosis and intracellular killing by polymorphnucleas and mononuclear phagocytes.Incited from, Weir DM. and Herzenberg LA., Handbook of Experimental Immunology, Vol.2, Cellular mmunology Black Scientific publications, Oxford, UK, pp.36. 1-36.24.

Vijayalakshmi, P; Prathaban, S. and Dhanapalan, P. (2001): Comparative study on the efficacy of diagnostic tests in the field diagnosis of bovine mastitis. Indian Vet. J. 68:4-6.

Vimercati, C.; Cremonesi, P.; Castiglioni, B.; Pisoni, G.; Boettcher, P.J.; Stella, A.; Vicenzoni, G. and Moroni, P. (2006): Molecular typing of Staphylococcus aureus isolated from cows, goats and sheep with intramammary infections on basis of gene polymorphisms and toxin genes. J. Vet. Med., 53: 423-428.

Zecconi, A. and Piccinini, R. (1999): Teoria e prática de controle de mastite por Staphylococcus aureus. Napgama , 5: 4-11 